\title{
Problem Solving Dalam Konseling Islam
}

\section{Problem Solving in Islamic Counseling}

\author{
Azizah Hanum OK \\ Fakultas Ilmu Tarbiyah dan Keguruan, Universitas Islam Negeri Sumatera Utara, Indonesia
}

Diterima : 05 Agustus 2020; Disetujui : 09 Agustus 2020; Dipublish : 29 Agustus 2020

*Corresponding author: E-mail: azizahhanumok@uinsu.ac.id

\begin{abstract}
Abstrak
Manusia kerap dihadapi oleh berbagai masalah. Masalah dapat dipahami sebagai salah satu bagian dari setiap perjuangan yang tidak dapat dihindari oleh setiap manusia. Setiap masalah terkadang terasa sangat berat, sehingga banyak manusia yang merasa sangat menderita manakala mendapatkan permasalahan. Sebagian bahkan memilih untuk mengakhiri hidupnya karena ketidakmampuannya untuk bertahan dan menghadapi masalah yang sedang dihadapi. Selalu ada keputusan-keputusan yang harus diambil oleh seseorang. Bahkan sikap tidak mengambil keputusan pada dasarnya adalah suatu bentuk pengambilan keputusan. Semuanya memiliki resiko. Dalam mengambil suatu keputusan, seseorang mesti melihat persoalan dari berbagai sudut pandang, karena apa yang baik bagi sebagian besar orang, belum tentu baik bagi diri sendiri.Islam memberikan bimbingan kepada individu agar dapat kembali kepada Alquran dan Hadis. Islam mengarahkan setiap individu agar dapat mengerti arti ujian dan masalah dalam hidup. Kegelisahan, ketakutan dan kecemasan merupakan 'bunga' kehidupan yang harus dapat ditanggulangi dan diganti dengan keberanian oleh setiap individu dengan memohon pertolongan-Nya, melalui orang-orang ahli.
\end{abstract}

Kata Kunci: Problem Solving, Konseling Islam

\begin{abstract}
Humans often present various problems. Problems can be implemented as a part of every struggle that cannot be avoided by every human being. Every problem sometimes feels very heavy, so that many people feel very suffering from problems. Some even chose to finish him off because of his inability to survive and face problems that were on track. There are always decisions that a person has to make. Even the decision to make a decision in reality is a decision making. Everything has risks. In making a decision, one must look at problems from various points of view, because what is good for most people is not necessarily good for oneself. Islam provides guidance to individuals so that they can return to the Koran and Hadith. Islam directs each individual to understand the meaning of tests and problems in life. Anxiety, fear and loss are the 'flowers' of life that must be overcome and replaced with courage by each individual by asking for His help, through skilled people.
\end{abstract}

Keywords: Problem Solving, Islamic Counseling

Rekomendasi mensitasi :

OK, A.H. 2020. Problem Solving Dalam Konseling Islma. Jurnal Penelitian Pendidikan, Psikologi dan Kesehatan (J-P3K), 1(2): 133-142. 


\section{PENDAHULUAN}

Sebagai makhluk yang tidak pernah luput dari problematika kehidupan, manusia telah dibentangkan dengan berbagai petunjuk dan solution (pemecahan. penyelesaian) terhadap problem kehidupan yang dihadapinya. Namun karena tidak semua problem dapat diselesaikan oleh manusia secara mandiri maka ia memerlukan bantuan seorang ahli yang berkompeten sesuai dengan jenis problemnya.Hidup secara tolong menolong dalam jalan kebaikan, saling mengingatkan dan memberi nasehat untuk kebaikan dan menjauhi kemungkaran (Lubis, 2007). Dengan demikian dalam konseling islami ini terjalin hubungan personal antara dua pihak, satu pihak ingin meecahkan masalah dan satu pihak lain membantu memecahkan masalah.

Manusia adalah makhluk unik dan istimewa, dibuktikan lewat keberadaan beragam kajian tentang manusia dalam berbagai perspektif, baik normatif, filosofis maupun empirik. Para ahli telah meneliti hakikat manusia, mulai dari penciptaan manusia, dimensi fisik dan psikisnya, karya dan dampaknya, serta masalah dirinya, masyarakat dan lingkungan hidupnya.

Mencari petunjuk Alquran dalam pelaksanaan konseling ataupun problem solving sangatlah tepat. Berkenaan dengan dimensi spiritual dalam konseling Islami, Allah swt ditempatkan pada posisi Konselor Yang Maha Agung, satu-satunya tempat manusia menyerahkan diri dan permasalahannya sebagai sumber penyelesaian masalah. Soekanto (2004) menjelaskan bahwa Problem Solving atau memecahkan masalah juga merupakan salah satu keahlian yang sangat penting untuk dimiliki seseorang karena tidak hanya berguna untuk memecahkan suatu masalah tertentu melainkan juga berguna untuk mencapai kesuksesan atau hal lain yang dicita-citakan.

\section{METODE PENELITIAN}

Penelitian ini termasuk dalam penelitian kualititaif, dengan metode yang digunakan untuk pengkajian ini adalah studi literatur. Pengumpulan data atau sumber literature diperoleh dari buku- buku teks, laporan hasil penelitian, skripsi dan jurnal penelitian. Data yang diperoleh kemudian dikumpulkan, dianalisis, dan disimpulkan sehingga mendapatkan kesimpulan mengenai studi literatur.

\section{HASIL DAN PEMBAHASAN}

\section{A. Pandangan Islam tentang masalah pada manusia}

Soekanto (2004) menjelaskan permasalahan adalah persoalanpersoalan yang dihadapi oleh seseorang yang terkait pada masalah pribadi yang mencakupi perasaan, nilai-nilai, kondisi fisik, penyerasian sosial, persoalan yang dihadapi di rumah dan masyarakat. Simpulannya adalah bahwa masalah dapat digambarkan sebagai suatu keadaan baik yang terlihat atau tidak terlihat di mana antara yang diharapkan tidak sesuai dengan kenyataan. Antara apa yang direncanakan tidak sesuai dengan kenyataan, atau terdapat hambatan antara yang diinginkan dengan keadaan sebenarnya.

Dalam hal ini, masalah berbeda dengan keluhan. Keluhan merupakan akibat dari masalah yang tidak jelas atau tidak teratasi. Keluhan yang dirasakan 
seseorang dapat dijadikan tanda bahwa seseorang sedang mengalami masalah yang tidak dikenali atau sebuah masalah yang tidak dipecahkan.

Dalam sudut pandang Islam, Allah swt menyatakan bahwa manusia diciptakan hanyalah untuk beribadah kepada-Nya. Dan aku tidak menciptakan jin dan manusia melainkan supaya mereka mengabdi kepada-Ku (Q.S. al-Dzâriyat/51: 56). Pernyataan ini menegaskan bahwa, jika ada manusia yang enggan beribadah kepada Allah, maka sebenarnya dia telah melanggar fungsi penciptaan manusia. Dalam konteks ini, pada dasarnya ibadah adalah sebuah bentuk perjuangan hidup yang diajarkan di dalam Islam. Agama ini mengajarkan bahwa umat Islam dilarang untuk hidup bermalas malasan. Islam mengajarkan umatnya untuk berjuang dalam kehidupan, karena Allah swt, menegaskan bahwa Dia tidak akan merubah nasib suatu kaum melainkan kaum itu sendirilah yang harus berjuang untuk merubah nasibnya.

Dalam menjalani kehidupannya sebagai hamba Allah swt, manusia kerap dihadapi oleh berbagai masalah. Masalah dapat dipahami sebagai salah satu bagian dari setiap perjuangan yang tidak dapat dihindari oleh setiap manusia. Setiap masalah terkadang terasa sangat berat, sehingga banyak manusia yang merasa sangat menderita manakala mendapatkan permasalahan. Sebagian bahkan memilih untuk mengakhiri hidupnya karena ketidakmampuannya untuk bertahan dan menghadapi masalah yang sedang dihadapi.

Dalam Q.S. al-'Ashr/103: 1-3, Allah SWT. berfirman: Demi masa, sesungguhnya manusia itu benar-benar dalam kerugian kecuali orang-orang yang beriman dan mengerjakan amal saleh dan nasehat-menasehati supaya menetapi kesabaran.

Dalam Q.S. al-Baqarah/2: 286, Allah SWT. berfirman: Allah tidak membebani seseorang melainkan sesuai dengan kesanggupannya. Ia mendapat pahala (dari kebajikan) yang diusahakannya dan ia mendapat siksa (dari kejahatan) yang dikerjakannya. (Mereka berdoa): "Ya Tuhan kami, janganlah Engkau hukum kami jika kami lupa atau kami bersalah. Ya Tuhan kami, janganlah Engkau bebankan kepada kami beban yang berat sebagaimana Engkau bebankan kepada orang-orang yang sebelum kami. Ya Tuhan kami, janganlah Engkau pikulkan kepada kami apa yang tidak sanggup kami memikulnya. Beri maaflah kami, ampunilah kami dan rahmatilah kami. Engkaulah Penolong kami, maka tolonglah kami terhadap kaum yang kafir.

Dalam Q.S. al-A'râf/7: 42, Allah berfirman: Dan orang-orang yang beriman dan mengerjakan amal-amal yang saleh, Kami tidak memikulkan kewajiban kepada diri seseorang melainkan sekedar kesanggupannya, mereka itulah penghunipenghuni surga, mereka kekal di dalamnya.

Berdasarkan ketiga ayat di atas, dapat dipahami bahwa setiap manusia yang hidup pasti akan menghadapi masalah. Namun, Allah tidaklah membebani manusia dengan masalah yang tidak sanggup dipikul oleh mereka. Karena Dia telah menganugerahkan beragam kemampuan untuk mampu menyelesaikan masalah hidupnya. Tentu saja, kemampuan ini tergantung sejauh mana manusia berhasil 
mengaktualisasikan potensi dirinya. Setiap permasalahan merupakan gudang hikmah yang sangat berharga. Dalam hal ini, banyak hikmah yang dapat dipetik melalui sebuah masalah, antara lain:

1. Masalah sebagai pembersih dosa.

2. Masalah sebagai peningkatan kualitas diri.

3. Masalah sebagai pengingat bagi umat.

Sebenarnya masalah atau sering juga disebut dengan istilah cobaan yang menimpa seseorang adalah bukti kasih sayang Allah swt kepada kita, hal itu dapat membersihkan/mensucikan seseorang dari berbagai macam bentuk dosa, bila tidak akan mencelakakan kehidupan akhirat kelak, dengan kesucian diri Allah swt menghendaki hambanya menemuinya, sebagaimana Hadis Rasulullah saw dalam H.R. al-Tirmidzî No. 2398: "Orang yang paling banyak mendapatkan ujian/cobaan (di jalan Allah Ta'ala) adalah para Nabi, kemudian orang-orang yang (kedudukannya) setelah mereka (dalam keimanan) dan orang-orang yang (kedudukannya) setelah mereka (dalam keimanan).

(Setiap) orang akan diuji sesuai dengan (kuat/lemahnya) agama (iman)nya, kalau agamanya kuat maka ujiannya pun akan (makin) besar, kalau agamanya lemah maka dia akan diuji sesuai dengan (kelemahan) agamanya, dan akan terus-menerus ujian itu (Allah Ta'ala) timpakan kepada seorang hamba sampai (akhirnya) hamba tersebut berjalan di muka bumi dalam keadaan tidak punya dosa (sedikit pun)".

Masalah juga merupakan salah satu media yang dapat meningkatkan kualitas diri seseorang sebagaimana Hadis
Rasulullah saw dalam H.R. Muslim No. 2999: "Alangkah mengagumkan keadaan seorang mukmin, karena semua keadaannya (membawa)kebaikan (untuk dirinya), dan ini hanya ada pada seorang mukmin; jika dia mendapatkan kesenangan dia akan bersyukur, maka itu adalah kebaikan baginya, dan jika dia ditimpa kesusahan dia akan bersabar, maka itu adalah kebaikan baginya".

Oleh karenanya menurut Rasulullah saw bahwa setiap manusia yang memiliki masalah itu sebagai penghapus dosa yang pernah diperbuatnya dan setiap masalah yang datang pasti akan teratasi dimana telah disesuaikan Allah swt dengan kemampuan orang yang menerimanya melalui keimanan dan ketaqwaan yang dimilikinya.

Masalah juga sebagai pengingat bagi seluruh umatnya, dengannya Allah menyadarkan kita bahwa kita adalah mahluk yang lemah tak berdaya tanpa kekuatan Allah swt, sebagaimana Hadis Rasulullah saw dalam H.R. Bukhârî No. 6053: "Jadilah kamu di dunia seperti orang asing atau orang yang sedang melakukan perjalanan", artinya kita harus sadar bagaimana kita menempatkan diri dalam kehidupan di dunia, orang asing dimaksud adalah ibarat perantau yang harus kembali ke tempat asal dengan sebuah keberhasilan menuju jalan Allah swt.

\section{B. Potensi dasar manusia dalam menyelesaikan masalah}

Para ahli menyatakan bahwa manusia memiliki sejumlah potensi. Ibn Sînâ mengatakan "sesungguhnya setiap manusia dilandasi kekuatan-kekuatan." Manusia memiliki tiga potensi luar biasa 
yang terdapat dalam diri setiap orang yang dapat dijadikan sumber dalam menyelesaikan masalah yaitu potensi jasmani, potensi akal dan potensi ruhani. Bobbi Deporter (2007) berkata "ketika anda menyadari potensi murni yang berada di dalam diri anda, ketika anda mengetahui betapa banyak yang mampu anda lakukan sekarang anda akan masuk kedalam gairah sukses." Apabila potensi tersebut dimanfaatkan secara arif bahkan disinergikan dengan baik, maka akan menghasilkan pribadi yang menawan, profesional dan terbebas dari beragam masalah.

\section{Potensi Jasmani}

Manusia memiliki jasmani yang sempurna, penglihatan yang baik, pendengaran yang jelas, penciuman yang baik, mulut yang bisa digunakan untuk komunikasi, kaki dan tangan yang kuat, kelenturan tubuh yang baik sehingga manusia bisa melakukan segala aktivitas yang digelutinya, sebagaimana firman Allah swt dalam Q.S. al-Thîn/95:4. Manusia memiliki bentuk yang terbaik dari segala ciptaan Tuhan yang lain, bentuk tubuh yang terbaik ini memiliki potensi yang sangat besar, banyak hal yang dapat dikembangkan dari potensi jasmani, karena sesungguhnya semua aktivitas manusia yang melakukannya adalah jasmani manusia itu sendiri.

\section{Potensi Akal}

Akal adalah salah satu potensi manusia yang sangat istimewa. Dalam hal ini, akal menjadi pembeda antara manusia dengan binatang, tumbuhan, bahkan malaikat sekalipun. Seharusnya, manusia harus memanfaatkan potensi akalnya dengan baik, misalnya memikirkan ayat- ayat qauliyah (tersurat) dan ayat-ayat kauniyah (tersirat). Saktiyono di dalam bukunya Psikologi Islami mengatakan bahwa pada manusia telah diberikan potensi kehidupan dan potensi akal. Saktiyono dan Purwoko (2012) Lebih lanjut Saktiyono mengatakan potensi akal tidak termasuk dalam potensi kehidupan, karena manusia masih bisa hidup meskipun potensi akalnya hilang atau belum sempurna. Meskipun demikian, potensi akal merupakan potensi manusia yang paling penting karena dengan potensi akalnya manusia mampu menciptakan peradaban.

\section{Potensi Ruhani}

Ruhani adalah mencakup interelasi antara hati, jiwa, dan ruh. Halim (2000) mengemukakan dari tiga potensi manusia, baik jasmani, akal maupun ruhani, maka ruhani menjadi potensi yang paling menentukan kualitas seseorang. Realita menunjukkan bahwa banyak orang memiliki fisik kuat dan akal cerdas, tetapi masih memiliki sifat tercela seperti sombong, tidak mau menerima nasihat, merendahkan orang lain, dan merasa dirinya paling benar dan hebat. Pada dasarnya, orang tersebut berada dalam masalah yang besar, meski ia sendiri tidak menyadarinya. Manusia seperti itu justru akan menyusahkan dirinya sendiri, karena banyak orang tidak akan menyukainya karena sifat buruk tersebut. Diungkap Plato "keberhasilan manusia dalam hidup sangat bergantung dengan kekhusukan ruhaniahnya dan kedekatannya, serta kecenderungannya dengan ruh Ilahi dalam tubuhnya tersebut. Orang-orang yang tidak menyadari kekuatan potensi dirinya, 
maka mereka akan selalu ditimpa masalah tanpa solusi.

\section{Keberanian mengambil keputusan}

Setiap orang menginginkan yang terbaik dari hidup ini. Tidak seorang pun senang akan kemiskinan atau hidup dalam keadaan paspasan. Tidak seorang pun senang merasa inferior, tidak seorang pun senang dipermainkan (Halim, 2000). Untuk memilih sebuah keputusan, seseorang membutuhkan keyakinan, jika kita tidak yakin maka hasilnyapun bisa menjadi tidak maksimal. Lulu Kemaludin mengatakan 'Jika anda tidak yakin "anda bisa," maka anda pun tidak akan maksimal melakukannya, potensi yang ada pada diri andaipun tidak ter-eksplore secara maksimal, dan hasilnya pasti tidak akan maksimal' (Kemaludin, 2011).

Rahmat di dalam bukunya Dari Tidak Bisa Menjadi Bisa mengatakan 'jika para mujahid dengan gagah berani maju ke medan tempur, tidak takut kena panah, tidak takut kena pedang, tidak takut disiksa, tidak takut ditawan, bahkan tidak takut mati meski dengan leher terpenggal, karena mereka memililki keyakinan bahwa balasan hari esok di surga akan melebihi pengorabanan apa pun yang diberikan saat ini', coba kita bayangkan seandainya para mujahid tidak memiliki keyakinan seperti yang dikatakan oleh Rahmat, maka pastilah Islam hanya akan tinggal sejarah.

Konklusinya, bahwa dalam hidup, selalu ada keputusan-keputusan yang harus diambil oleh seseorang. Bahkan sikap tidak mengambil keputusan pada dasarnya adalah suatu bentuk pengambilan keputusan. Semuanya memiliki resiko. Dalam mengambil suatu keputusan, seseorang mesti melihat persoalan dari berbagai sudut pandang, karena apa yang baik bagi sebagian besar orang, belum tentu baik bagi diri sendiri. Semua pilihan kembali pada diri sendiri, dan untuk dapat keluar dari sebuah persoalan atau permasalahan, seseorang membutuhkan keberanian mengambil sebuah keputusan, meskipun keputusan yang diambil cukup pahit.

\section{Langkah-langkah pengambilan keputusan yang tepat}

Tidaklah mudah mengambil suatu keputusan, jika gagal masalah bias menjadi besar, sehingga membutuhkan pengambilan keputusan yang lebih arif dan bijaksana lagi meskipun dapat mengakibatkan resiko yang lebih besar. Metode problem solving adalah salah satu dari kegiatan metode ingkuiri yang paling sering digunakan. Metode ingkuiri juga disebut metode penyelesaiaan masalah atau discovery. Ingkuiri lebih memberi tekanan pada keyakinan atas dirinya sendiri terhadap apa yang ditemukan, metode problem solving lebih menekankan pada terselesaikannya masalah itu sendiri, sedangkan discovery pada penemuan itu sendiri.

Teknik pengambilan keputusan dalam problem solving memerlukan keterampilan yang harus dimiliki. Pengambilan keputusan merupakan ilmu dan seni yang harus dicari, dipelajari, dimiliki, dikembangkan secara mendalam oleh setiap orang. Dikatakan seni adalah karena kegiatannya selalu dihadapkan pada sejumlah peristiwa yang memiliki karakteristik dan keunikan tersendiri. Sedangkan dikatakan ilmu adalah karena aktivitasnya memiliki sejumlah cara, 
metode, atau pendekatan yang bersifat sistematis, teratur dan terarah.

Adapun langkah-langkah dalam teknik pengambilan keputusan dalam rangka roblem solving menurut Supranto (2004) adalah:

\section{Pengumpulan}

\section{fakta/data/Informasi.}

Tujuan dari mengumpulkan fakta, data atau informasi untuk mengetahui penyebab mendasar dari permasalahan; mengetahui potensi yang tepat untuk memecahkan masalah dan sebagai acuan untuk merumuskan berbagai alternative tindakan yang dapat dilakukan untuk memecahkan masalah.

\section{Menemukan berbagai alternative tindakan.}

Alternatif tindakan didesign berdasarkan fakta, data dan informasi yang terkumpul. Temukanlah sedapat mungkin alternatif tindakan dari fakta, data dan informasi tersebut dengan memperhitungkan fakta, data dan informasi yang ada.

\section{Memilih atau menentukan alternative tindakan yang ada.}

Siagian mengemukakan terdapat tujuh langkah yang dapat ditempuh dalam memilih atau menentukan tindakan. Pertama, mengetahui hakikat masalah yang dihadapi. Dengan perkataan lain, mendefinisikan masalah yang dihadapi dengan setepat-tepatnya. Kedua, mengumpulkan fakta-fakta dan data yang relevan. Ketiga, mengolah fakta-fakta dan data tersebut. Keempat. Menentukan beberapa alternatif yang mungkin ditempuh. Kelima, memilih cara pemecahan dari alternatif yang telah diolah dengan matang. Keenam, memutuskan tindakan yang hendak dilakukan. Ketujuh. Menilai hasil-hasil yang diperoleh sebagai akibat dari keputusan yang telah diambil (Siagian, 1998).

\section{Implementasi dan evaluasi.}

Secara sederhana implementasi bisa diartikan sebagai pelaksanaan atau penerapan. Penerapan yaitu tahap melaksanakan keputusan dan melaporkan hasilnya. Implementasi juga sebagai evaluasi. Evaluasi perlu dilakukan dalam rangka memperoleh data dari hasil pengukuran yang akan digunakan untuk melihat efektifitas tindakan yang telah dilakukan dalam mencapai tujuan. Evaluasi juga diperuntukkan untuk menganalisis kegiatan yang telah dilakukan untuk menentukan tindakan yang lebih lanjut manakala tujuan belum tercapai secara maksimal, sehingga dari hasil evaluasi dapat dilakukan perbaikan.

\section{Berdoa}

Segala usaha atau ikhtiar yang dilakukan tidak akan ada artinya jika tidak diiringi dengan doa. Begitu juga sebaliknya, doa yang dipanjatkan, tidak akan ada artinya jika tidak diihtiarkan, semuanya saling berkaitan. Setiap orang harus meyakini bahwa Allah lah yang menentukan segala hasil dari setiap ikhtiar manusia. Bisa jadi apa yang menurut seseorang itu adalah sesuatu yang baik, tetapi belum tentu baik di sisi Allah, bisa jadi apa yang ia usahakan dan minta adalah sesuatu yang menurut Allah tidak baik, sehingga Allah memiliki jawaban yang lain untuknya.

\section{E. Upaya konseling Islam dalam menumbuhkan keberanian manusia}


Manusia diciptakan dalam keadaan yang terbaik, termulia, dan tersempurna dibandingkan dengan makhluk lainnya, meskipun tetap memiliki hawa nafsu dan perangai buruk. Pada dasarnya, hakikat Bimbingan Konseling Pendidikan Islami hampir sama dengan Bimbingan Koseling konvensional. Perbedaannya terletak pada orientasi, substansi dari alternatifalternatif solusi yang ditawarkan, dan semua prosesnya mengacu kepada Alquran dan Hadis. Adian Husaini menuliskan bahwa prestasi-prestasi besar kaum Muslim di bidang kehidupan dan keilmuan tidaklah terpisah dari dorongan besar yang diberikan kitab suci Alquran dalam pengembangan ilmu pengetahuan (Husaini, 2010). Alquran adalah kitab yang begitu besar perhatiannya terhadap aktivitas pemikiran dan keilmuan.

Sesungguhnya Islam memberikan bimbingan kepada individu agar dapat kembali kepada Alquran dan Hadis. Islam mengarahkan setiap individu agar dapat mengerti arti ujian dan masalah dalam hidup. Kegelisahan, ketakutan dan kecemasan merupakan 'bunga' kehidupan yang harus dapat ditanggulangi dan diganti dengan keberanian oleh setiap individu dengan memohon pertolonganNya, melalui orang-orang ahli.

Secara teoritis, ada lima tujuan konseling dalam Islam. Pertama. Untuk menghasilkan suatu perubahan, perbaikan, kesehatan dan kebersihan jiwa dan mental. Kedua. Untuk menghasilkan suatu perubahan, perbaikan dan kesopanan tingkah laku yang dapat memberikan manfaat baik pada diri sendiri, lingkungan keluarga, lingkungan kerja maupun lingkungan sosial dan alam sekitarnya. Ketiga. Untuk menghasilkan kecerdasan rasa pada individu sehingga muncul dan berkembang rasa toleransi, kesetiakawanan, tolong menolong dan rasa kasih sayang.

Keempat. Untuk menghasilkan kecerdasan spiritual pada diri individu sehingga muncul dan berkembang rasa keinginan untuk berbuat taat kepada Tuhannya, ketulusan mematuhi segala perintah-Nya serta ketabahan menerima ujian-Nya. Kelima. Untuk menghasilkan potensi Ilahiah, sehingga individu dapat melakukan tugasnya sebagai khalifah dengan baik dan benar (Al-Dzaky, 2001).

Hamdani mengatakan fungsi Bimbingan Konseling Pendidikan Islam meliputi fungsi remedial atau rehabilitatif, fungsi edukatif, dan fungsi preventif. Fungsi Bimbingan Konseling dalam Islam tidak dapat terpisahkan dengan masalahmasalah spiritual (keyakinan). Setelah individu tersebut mampu kembali dalam kondisi yang fitri, barulah dikembangkan ke arah pengembangan yang baik bagi mereka. Kemampuan potensial manusia yang diberikan Allah swt yakni kemampuan mengarah kepada hubungan manusia dengan tuhanNya, sesama dan dengan alam.

\section{Hubungan Manusia dengan Tuhan (habl min Allah)}

Pelaksanaan bimbingan dan konseling dipastikan akan mampu mengarahkan konseli kepada kebenaran bahkan keberanian dan perlu memiliki tiga langkah untuk menuju pada kesuksesan bimbingan dan konseling. Pertama, memiliki mission statement yang jelas yaitu dua Kalimat Syahadat. Kedua, memiliki sebuah metode pembangunan karakter sekaligus simbol kehidupan, yaitu salat lima waktu. Ketiga, 
memiliki kemampuan pengendalian diri yang dilatih dan disimbolkan dengan puasa.

Jika seseorang telah bergantung kepada Yang Maha Besar, maka sesungguhnya tidak ada lagi yang perlu dikhawatirkan atau ditakutkan. Allah berfirman dalam surat al-Ikhlâsh/112: 14, Katakanlah "Dia-lah Allah, yang Maha Esa, Allah adalah Tuhan yang bergantung kepada-Nya segala sesuatu. Dia tiada beranak dan tidak pula diperanakkan, dan tidak ada seorang pun yang setara dengan-Nya."

\section{Hubungan Manusia dengan Manusia (habl min al-nas)}

Salah satu ketentuan yang diberikan Allah SWT. adalah seperti di dalam Q.S. Âli 'Imrân/3: 104, Dan hendaklah ada di antara kamu suatu umat yang menyeru berbuat kebaikan, dan menyuruh orang melakukan yang benar, serta melarang yang mungkar. Merekalah orang yang mencapai kejayaan. Ayat di atas secara jelas menggambarkan bahwa manusia harus saling bekerja sama untuk mencapai kebahagiaan duni dan akhirat. Para nabi yang diutus oleh Allah swt. Juga bertugas sebagai figur konselor yang mumpuni dalam memecahkan permasalahan (problem solving) yang berkaitan dengan jiwa manusia, agar manusia keluar dari tipu daya setan.

\section{Hubungan Manusia denga Alam (habl min al-'alam)}

Menyadari eksistensinya sebagai makhluk Allah, berarti manusia tersebut akan berperilaku sesuai dengan ketentuan dan petunjuk Allah. Dengan hidup seperti itu, maka akan tercapailah kehidupan yang bahagia dengan alamnya. Allah swt berfirman dalam Q.S. Hûd/11:
61, Dan kepada Tsamud (Kami utus) saudara mereka Shaleh. Shaleh berkata 'Hai kaumku, sembahlah Allah, sekali-kali tidak ada bagimu Tuhan selain Dia. Dia telah menciptakan kamu dari bumi (tanah) dan menjadikan kamu pemakmurnya karena itu mohonlah ampunan-Nya, kemudian bertobatlah kepada-Nya, sesungguhnya Tuhanku amat dekat (rahmat-Nya) lagi memperkenankan (doa hamba-Nya)."

Di dalam Q.S. al-A'râf/7: 56, Allah SWT. berfirman: Dan janganlah kamu membuat kerusakan di muka bumi, sesudah (Allah) memperbaikinya dan berdoalah kepada-Nya dengan rasa takut (tidak akan diterima) dan harapan (akan dikabulkan). Sesungguhnya rahmat Allah amat dekat kepada orang-orang yang berbuat baik.

\section{SIMPULAN}

Masalah dipahami sebagai suatu keadaan, baik itu terlihat atau tidak terlihat di mana antara yang diharapkan tidak sesuai dengan kenyataan. Antara apa yang direncanakan tidak sesuai dengan kenyataan, atau terdapat hambatan antara yang diinginkan dengan keadaan sebenarnya. Dalam perspektif Islam, setiap masalah atau cobaan adalah suatu pelajaran yang bernilai positif karena memiliki segudang hikmah, antara lain sebagai pembersih dosa, peningkatan kualitas diri dan pengingat umat.

Upaya memecahkan sebuah masalah dapat diawali dengan mengumpulkan fakta, data informasi dari yang berkaitan dengan masalah, kemudian menemukan berbagai alternatif dari fakta yang ada, dan kemudian menentukan alternatif yang ada untuk selanjutnya 
diimplementasikan serta dievaluasi, dan tentunya tidaklah lupa diserahkan usaha seseorang kepada Allah melalui doa.

Bimbingan Konseling Pendidikan Islami berupaya menumbuhkan sikap berani dalam mengambil keputusan ke dalam diri konseli sesuai dengan pandangan Alquran dan Hadis. Upaya menumbuhkan sikap berani dalam mengambil keputusantersebut dilakukan dengan menanamkan ketauhidan secara kokoh yakni menjaga hubungan dengan Tuhan, kemudian menjaga hubungan baik dengan sesama (manusia) serta tidak lupa menjaga hubungan baik dengan alam lingkungan sehingga apa bila ketiga hubungan itu terjaga dengan baik maka sesungguhnya tidak ada alasan lagi bagi manusia untuk tidak memiliki keberanian di dalam hidupnya.

\section{DAFTAR PUSTAKA}

Bobbi Deporter, Quantum Success: 8 Kunci Meraih Kesukesesan Luar Biasa di Mana pun , Kapan pun dan Siapa pun Anda, Bandung: Mizan, 2007.

Halim, Ali Abdul, Pendidikan Ruhani, Jakarta: Gema Insani Press, 2000.

Hamdani Bakran al-Dzaky, Psikoterapi Konseling Islam, cet. 2, Yogyakarta: Fajar Pustaka Baru, 2001

Husaini, Adian, Pendidikan Islam: Membangun Manusia Berkarakter dan Beradab, Jakarta: Program Pascasarjana Universitas Ibn Khaldun bekerjasama dengan Cakrawala Publishing, 2010.

Kemaludin, Lulu, Be Your Super Self: Langkah Demi Langkah Bagaimana Memaksimalkan Potensi Diri, Jakarta: Penerbit Kemaludin e-Publishing House, 2011.

Lubis, Saiful Akhyar, Konseling Islami dan Kesehatan Mental, Bandung: Citapustaka Media Perintis, 2011.

Konseling Islam, Kyai dan Pesantren, eLsaQ Press, Yogyakarta, 2007.
Purwoko B, Saktiyono B., Psikologi Islami: Teori dan Penelitian, Bandung: Saktiyono Wordpress, 2012.

Schwartz, David J, Berpikir dan Berjiwa Besar: The Magic of Thingking Big, Ciputat: Bina Rupa Aksara, 2007.

Siagian, S.P., Sistem Informasi Untuk Pengambilan Keputusan, Jakarta: Gunung Agung, 1980.

Soekanto, Soerjono, Sosiologi Keluarga, Jakarta: Andi Mahasatya, 2004.

Supranto, Lihat Johanes, Teknik Pengambilan Keputusan, Jakarta: Rineka Cipta, 1998; Rizky Dermawan, Pengambilan Keputusan Landasan Filosofis, Konsep, dan Aplikasi, Bandung: Alfabeta, 2004. 